\title{
Position of Belief in the Status of Freedom of Religion and Belief Based on the International Law, National Law, and Islamic Law
}

\author{
Rohmat $^{\text {la }}$, Siti Khoerunnisa ${ }^{\text {lb }}$, Regita Prameswari ${ }^{1 \mathrm{c}}$ \\ ${ }^{1}$ Students Faculty of Law Universitas Negeri Semarang (UNNES), Indonesia \\ a rohmat0817@ students.unnes.ac.id, ${ }^{b}$ nisakhoerun0@gmail.com, ${ }^{c}$ regitaprameswari1@gmail.com
}

\begin{abstract}
Indonesia is a country with a diversity of plural residents embraced and run in accordance with religious worship and beliefs adhered. However, differences of religion and belief this trust is often the one thing triggers conflict society that could be a potential disintegration of the nation. Community believers in Indonesia often experience discrimination or rejection from the community who embraced religion officially recognized in Indonesia. As a country based on the Godhead, Indonesia secure and protect the rights of citizens to embrace religion and belief that they believe in. Therefore, this research examine about the status of the position the belief in Freedom of Religion and Belief in Indonesia in the study of international law, national law, and Islamic law.
\end{abstract}

\section{Keywords: Religion, Position, Belief, National Law, International Law, Islamic Law}

\section{INTRODUCTION}

Every human being is born with a basic human right, that is Human Rights. Human Rights are the basic rights of every human being that should not be violated or removed by anyone. The logical consequence of the statement requires that every state and government protect and enforce that human right. For that reason, Indonesia has ratified several UN Conventions regarding human rights, including Covention Against Torture and Other Cruel, Inhuman or Degrading Treatment or Punishment (Convention against Torture and Other Cruel, Inhuman or Degrading Treatment or Punishment) with Law no. 5 of 1998. Furthermore, several laws and regulations are defined as Law no. 39 of 1999 on Human Rights, Law no. 26 of 2000 on the Human Rights Court and the top is the amendment of the 1945 Constitution. [1]. One of the basic rights that can not be reduced or eliminated or Underogable rights is the Right of Religion and Belief.

In the Constitution of the Republic of Indonesia Year 1945 Article 29 paragraph (2) mentions "the country guarantess the independence of each population to embrace his religion and to worship according to his religion and beliefs"[2]. The implications of the article requires the State and the Government of Indonesia guarantees the existence of the freedom of every citizen to embrace religion and worship according of religion and beliefs were. Human rights are rights belonging to man solely because he was a human being. The human race had it not been for given to him by the public or based on positive law, but rather solely on the basis of his dignity as a human being. That is, although the skin color, gender, language, culture, and citizenship, human beings still have those rights.

However, although has been arranged and secured in such a way, a violation of the right of freedom of religion and belief was still going on. Based on the annual report on freedom of religion and Belief of the year 2016 issued by Komnas HAM stated the number of complaints of violations of the rights of freedom of religion and belief received KOMNAS HAM in 2016 (January-December) amounted to 97 complaints (complaint on average per month). That number increased from the number of complaints the year 2015 which totaled 87 complaints[3].

Appropriate legal framework of HUMAN RIGHTS, everyone enjoyed a double protection granted by national legal systems and international law. The fundamental weaknesses in the implementation of the provisions of International HUMAN RIGHTS in Indonesia is not formulated expressly the position of international law into national law by the structure of the CONSTITUTION of the Republic Indonesia 1945. It is becoming the issue because the CONSTITUTION of the Republic Indonesia 1945 do not have such provisions sec. 39 of The Constitution of the Republic of South Africa (1996) which encrypts: 1) When interpreting the Bill of Rights, (a) a court, tribunal or forum must promote the values that underlie an open and democratic society based on human dignity, equality and freedom; (b) must consider international law; and (c) may consider foreign law disagree[4].

Believers in Indonesia often suffered discrimination, oppression, or even violent. In the exercise of the right of life and associating with other societies often feel excluded. Though clearly regulated in Law No. 39 of 1999 on human rights article 4 mentions "the right to life, the right to be tortured, the right to personal freedom, thought and conscience, the right to religion, the right not to be enslaved, the right to be recognized as the personal and the similarities before the law, and not to be prosecuted on the basis of retroactive laws are human rights that can not be reduced under any circumstances and by anyone"[5]. Based on the terms of this research will examine the position of the belief in freedom of religion and belief based on international law, national law, and Islamic law and the relationship between international law, national 
law, and the law Islam in ensuring protection of believers in Indonesia.

\section{RESEARCH METHOD}

Type of research: The type of research method used is qualitative research method. Qualitative research is a study that refers to the legal norms contained in legislation and norms that developed in society. apparatus[6].

Approach to the research: the research used in the juridical normative approach. Juridical normative approach to the law is carried out based on the primary law materials by way of studying the theories, concepts, principles of the law and legislation related to this research.

Source and Data Types: The data sources in this study used secondary data sources from primary legal materials and secondary legal materials. In the secondary data using primary legal materials will use the Law no. 39 of 1999 on Human Rights, Law no. Law No. 40 Year 2008 on the Elimination of Racial and Ethnic Discrimination, Universal Declaration of Human Rights, and the 1945 Constitution of the Republic of Indonesia. Secondary data with secondary legal materials will use the books and legal scientific writings related to the object of this study, the right formula for finding a position of trust in the right to freedom of religion and belief under international law, national law, and Islamic law.

The technique of Data collection: Data collection Techniques used in this study using the method of data collection the library. The collection of data by the method of collection of data obtained through library research libraries are sourced from legislation, books, official documents, publications and research results related to human rights against freedom of religion and belief.

Data Analysis: Data analysis used in this research is normative analysis. Normative analysis is how to interpret and discuss the results of research based on the understanding of law, legal norms, legal theories and doctrines related to the subject matter studied.

\section{RESUlTS AND DisCUSSION}

\section{A. Freedom of Religion and Belief in Indonesia}

One of the agenda in the life of nation and state is to maintain unity and unity of the nation and build prosperity of life with all citizens and religious people one of them by guaranteeing freedom of religion and belief for every citizen[7]. Talking about the freedom of religion and belief in Indonesia has been guaranteed by the legislation system in Indonesia. This is stated in Law No.39 of 1999 on Human Rights Article 22 paragraph (1) "Everyone is free to embrace his or her own religion and to worship according to his religion and belief; (2) "The State guarantees the freedom of every individual to his or her religion and to worship according to his or her religion and belief'[8]. And the Indonesian Charter of Human Rights endorsed by the People's Consultative Assembly through its decision No.VII / MPR / 1988 which affirms the right of everyone to free to embrace their respective religions and worship according to their religion and belief. The formulation of the Constitution on Human Rights is the legal basis and guarantee of freedom of conscience for all Indonesian citizens.

Based on MPR Decree No.XVII / MPR / 1988 on Human Rights, recognize as follows: (1) The Indonesian people have views and attitudes about human rights derived from religious teachings, universal moral values, and noble values of national culture, and based on Pancasila and the 1945 Constitution; (2) The United Nations as a member of the United Nations has a responsibility to respect[9] the Universal Declaration of Human Rights and other instruments concerning Human Rights[10].

And in Article 29 of the CONSTITUTION of 1945 asserted that the State based upon the divinity of the Almighty, the State guarantees the independence of each population to embrace his religion and to worship according to his religion and beliefs were. The State not only guarantees freedom of religion, as well as the country embraced guarantee, protect, nurture, develop and provide guidance and direction, so that the religious life can flourish in harmony with the Government's wisdom in building the life of nation and State based on Pancasila. The State does not intervene and want to set up Islamic law and religious devotions, which generally form in the flow of religious belief according to each wholly guaranteed by the State[11].

\section{B. Particularistic of Human Rights to Freedom of Religion and Belief in Indonesia}

The Universal Declaration of Human Rights (UDHR) is a treaty that promotes respect for human rights and fundamental rights that serve as an international reference in view of human rights. The Universal Declaration of Human Rights became the International reference in determining the limits and standardization of human rights, which basically adhered to the values of freedom, justice and peace. The Universal Declaration of Human Rights states that all human beings are born free, equal, and have individual dignity and rights. However, the implementation of human rights applies relative to each country and is highly dependent on the interpretation of each country. The difference between this international and national understanding raises the debate between universalism and the particularism of human rights, universally human rights are seen as an idea of freedom despite the thickness of Western influence[12]. According to the study of Rhona K. Smith there are differences in the philosophical concepts of human rights. Where the Western countries always defend their priorities on human rights.

Based on the ideology of Universalism States that the more the culture of "Primitive" which eventually evolved to then have a system of law and equal rights with Western culture. In universalism, the individual is a unit that has rights that can not be denied, and directed at the fulfillment of personal interest. While based on 
Islamic law, the concept of sovereignty which embraced islam and adopted was that of the Eastern countries namely teaching the sovereignty of God, not merely state sovereignty or the concept of theocracy[13]. Talks about of human rights leads to the rights given by God as the Supreme sovereignty of the holder[14].

In essence, Human Rights are universal, looking at the nature attached to each individual. In terms of freedom of religion and belief the Indonesian nation itself has had customary values, cultural values and a belief passed down from generation to generation from ancestors long before the "Import" religion came to Indonesia. Therefore, the noble values and beliefs are still recognized and protected by the State as a form of guaranteeing freedom of religion and belief for every Indonesian citizen.

C. The Position of The Belief In Freedom of Religion and Belief Based on International Law, National Law, Islamic Law

\section{- Position of Belief Based on International Law}

In international law instruments, there is a recognized human rights as an absolute right. An absolute right is a right which cannot be limited by anything, anytime and anywhere. While the nonabsolute right is a right that can be subject to restrictions and prohibitions as long as the reasons for the prohibition are in the interest of law enforcement. Absoulute rights are known as non-derogable rights which means that they cannot be restricted under any circumstances even in situations that threaten the needs of a country. The right to freedom of opinion, religion and belief is contained in article 18 of International Conventions on Civil and Political Rights (ICCPR). The freedom to embrace religion and belief is also contained in Article 18 and 19 of Universal Declaration of Human Rights (UDHR) which regulates rights and freedoms without any exceptions, such as race, color, sex, language, religion, politics or different opinions, national or community origin, property, birth or other positions. Universal Declaration Of Human Rights is a recognition of human rights. The Declaration provides recognition of basic human rights. In it, it is explained that the recognition of basic human rights is the basis of world peace, justice and peace. Further, it is described that human rights need to be protected by law to create freedom of speech, religion, freedom from fear, and lack of humanity.

The United Nation General Assembly adopted the Universal Declaration of Human Rights as a common standard for success for all nations and countries. The Universal Declaration of Human Rights has a strong influence both directly and indirectly to the law that regulates human rights in general. Under Article 68 of the UN Charter, ECOSOC, has an obligation to establish a commission on economic and social affairs as well as to support human rights issues[15]. Recognition of the rights of freedom of religion and embracing the flow of trust continues to grow throughout the world. Therefore, freedom of religion and belief is the most basic human right, embedded in the human body and cannot be separated by anyone and by anything[16]. Therefore, the position of freedom of religion and belief has an important position to be protected by a country.

\section{- Position of Belief Based on National Law}

Freedom of religion and belief creates a state of affairs in a society in which a human can claim the highest spiritual goals without being obstructed by others. Freedom of religion and belief implies the existence of equal rights for every citizen to determine and determine the choice of religion and belief that will be embraced, perform the worship and everything related to that religion or belief.

Freedom of religion and belief in Indonesia is guaranteed in the 1945 Constitution of CHAPTER IX Article 29 paragraph (2). It is mentioned in the constitution that the state guarantees the freedom to embrace their respective religions and worship according to their religion and belief[17]. Indonesia is a democracy based on the state of Pancasila. Pancasila as the ideology of the nation is essentially not only a product of one's thinking, but Pancasila is lifted from the values of customs, cultural values, and religious values contained in the Indonesian society's life view before forming a religion. In Pancasila democracy, freedom of religion and belief is freedom with the principle of kinship, it implies that there is no adherents of the majority with adherents of minorities. Therefore, Indonesia understands the freedom of religion and belief based on the principles of Pancasila democracy and reflection of every precepts found in Pancasila[18].

So the concept of freedom of religion and belief adopted in Indonesia is freedom of religion and belief in accordance with Pancasila democracy and reflects the principles of Pancasila. Therefore, virtually all Indonesian citizens have the right to choose a spiritual relationship by remaining based on Pancasila. The position of freedom of religion and freedom of belief has the same position in the order of life of the nation and the state.

In article 2 of Law no. 39 of 1999 on Human Rights states that the state of the Republic of Indonesia recognizes and upholds human rights and fundamental human freedoms as rights that are naturally attached to and inseparable from human beings who must be protected, respected and enforced for the improvement of human dignity, prosperity, happiness, and intelligence and justice[19]. Therefore, the existence of human rights to freedom of religion and belief has been recognized legally by the state of Indonesia

\section{- Position of Belief Based on Islamic Law}

In Universal Declaration of Human Rights, Articles 18 and 19 states that freedom of thought, belief, religion, expressing opinion is a fundamental right and possessed by every human being. According to Maahood A. Baderin, the interpretation of the right to freedom of thought, belief and religion includes the freedom of changing religion or even embracing 
atheistic views raising controversy among Islamic scholars in relation to the problem of apostasy according to Islamic Law[20]. In Q.S. Al-Baqarah verse 256 which means "There is no compulsion to (enter) religion (islam); Indeed, the path is clearer than the way that is lost. Therefore Whoever denies Thaghut and believes in Allah, Truly is holding on to the very strong rope that will not break. And Allah is Hearing, Knower.

From the noise of the verse above the idle that "There is no compulsion in religion", according to Baderin a Muslim is obliged by his belief which he believes as the only truth, to make his claims to man not dogmatically or coercively but rationally through intellectual persuasion, wise debates, and balanced teaching. However, some traditional Qur'anic commentaries such as At-Thabari argue that the verse "no compulsion" applies only to ahlul kitab (Christians and Jews). Thabari's view is based on the reason for the fall of the verse. He said that two sons of a Muslim from the tribe of Salim Ibn Awf, both of whom had embraced Christianity prior to the arrival of Islam visited his father in Medina. The father was very sad to see his two children and asked them to move to Islam, but they both refused. The father then took both to the Prophet Muhammad and asked him to intervene.

At that moment the verse "no compulsion" is revealed, and the person must let his two sons embrace their beliefs. Considering that the revelation occasioned specifically relates to Christianity or the Ahlul religion of the book and does not apply to pagans. If this view is followed, it will deny freedom of thought, belief and religion to others as protected by international human rights law[21].

In Q.S. an-Nahl verse 125 which means "O Muhammad take the man, the religion of your Lord, with strong hujjah-hujjah, good advice and refute your opponent's hujjah with better hujjah. Verily your Lord knows all who pervert His religion, and Allah is Knower of those who receive guidance"[22]. In the verse, explaining that we are allowed to "invite" someone to convert to Islam, but should not insist on converting to Islam. Therefore, Article 10 of the Qairo Declaration on Human Rights in Islam states that "Islam is the religion of true unspoiled naturre. It is prohibited to exercise any form of pressure on man or to exploit his or her religion in order to change his religion to another religion or to atheism.

\section{CONCLUSIONS}

Human rights are basically a Universal right, but in the actualization of Human Rights are Particularistic. This implies that in exercising its rights must conform to the values or norms prevailing in that country. Human rights that flavor in accordance with the cultural or moral values that exist in the country. Thus, in exercising his rights one can adjust to the existing environment. The Right of Freedom of Religion and Belief firmly has a position to be protected and always upheld by all human beings. The position to choose their beliefs and perform their worship in accordance with their beliefs has earned recognition of the legal status and protection of the government and the state of Indonesia for the followers of religion and belief both in international law, national law and in Islamic law which does not impose a person to convert to Islam with violence. However, the Indonesian people tend not to understand how the concept of understanding of freedom of religion and belief, so that often there is friction in society.

\section{REFERENCES}

[1] Nurul Qamar, Hak Asasi Manusia dalam Negara Hukum Demokrasi (Human Rights in Democratiche Rechtsstaat), Jakarta: Sinar Grafika, 2014.

[2] Pasal 29 ayat (2) UUD NRI Tahun 1945.

[3] Laporan Tahunan Kebebasan Beragama dan Berkeyakinan KOMNAS HAM 2016.

[4] Titon Slamet Kurnia, Interpretasi Hak-Hak Asasi Manusia Oleh Mahkamah Konstitusi Republik Indonesia, Bandung: CV Mandar Maju, 2015.

[5] Pasal 4 Undang-Undang Nomor 39 Tahun 1999 tentang Hak Asasi Manusia.

[6] Zainuddin Ali, Metode Penelitian Hukum, Jakarta: Sinar Grafika, 2013.

[7] Siti Musdah Mulia, Hak Asasi Manusia dan Kebebasan Beragama, Diskusi Panel Perkembangan Konsep Tindak Pidana Dengan Agama Dalam Pembaharuan KUHP, Aliansi RKUHP, 2017.

[8] Pasal 22 Undang-Undang Nomor 39 Tahun 1999 tentang Hak Asasi Manusia.

[9] Titon Slamet Kurnia, Interpretasi Hak-Hak Asasi Manusia oleh Mahkamah Konstitusi Republik Indonesia The Jimly Court 2003-2008, Bandung, 2015.

[10] Tim Penyusun, Naskah Komprehensif Perubahan Undang-Undang Dasar Negara Republik Indonesia Tahun 1945: Latar Belakang, Proses dan Hasil Pembahasan 1999-2000: Buku VIII Warga Negara dan Penduduk, Hak Asasi Manusia dan Agama, , Jakarta: Penerbit Sekretariat Jenderal dan Kepaniteraan Mahkamah Konstitusi, 2010.

[11] Mudzakir, Peran Departemen Agama Dalam Pembinaan Kerukunan Umat Beragama, Jakarta: Lembaga Dakwah Islam Indonesia (LDII) dan Komisi Nasional Hak Asasi Manusia, 2005.

[12] Ani. W. Soetjipto, HAM dan Politik Internasional: Sebuah Pengantar, Jakarta: Yayasan Pustaka Obor Indonesia, 2015.

[13] Abdul A'la Al-Maududi, Hak Asasi Manusia Dalam Islam, terjemahan oleh Bambang Iriana Djajaatmadja, Jakarta: Bumi Aksara, 2000.

[14] Mujaid Kumkelo, Moh. Anas Kholish, dan Fiqh Vredian Aulia Ali, FIQH HAM Ordoksi dan Liberalisme Hak Asasi Manusia Dalam Islam, Malang: Setara Press, 2015.

[15] Isi Pasal 68 Piagam PBB: "Shall set up comissions in economic and social fields and for the promotion of human rights.

[16] Rizky Adi Pinandito, Implementasi Prinsip Kebebasan Beragama dan Berkeyakinan di Indonesia (Studi Kasus: Tanggung jawab Dalam Konflik Sampang, Madura), Jurnal Pembaharuan Hukum, Volume IV, Nomor 11, Januari-April 2017.

[17] Pasal 29 ayat (2) Undang-Undang Dasar Negara Republik Indonesia Tahun 1945.

[18] Mentary Meidiana, Menguatkan Konsep Kebebasan Beragama di Indonesia Sesuai dengan Pancasila dalam 
Mempertahankan Kesatuan Bangsa, Volume 3, Nomor 1, Desember 2007.

[19] Andrey Sujatmoko, Hukum HAM dan Hukum Humaniter, Jakarta: RajaGrafindo Persada, 2015.

[20] Mashood A. Baderin, International Human Rights and Islamic Law, yang diterjemahkan bahasa Indonesia oleh Musa Khazim dan Edwin Arifin dengan judul "Hukum Nasional, Hak Asasi Manusia, dan Hukum Islam,
Jakarta: Penerbit Komnas HAM, 2007.

[21] Muhammad Nur Islami, Hukum Internasional dalam Perspektif Islam dan Kedaulatan Bangsa, Yogyakarta: Pustaka Pelajar, 2017.

[22] Al-Qur'an Terjemahan Tafsiriyah, terjemah oleh Ustadz Muhammad Thalib, Yogayakarta: Penerbit Ma'had AnNabawy, 2012. 